International Journal of Business Management, Entrepreneurship and Innovation, Volume 3, Issue 2, 2021, PP 90-105, ISSN 2707-8027

\title{
Marketing Communication Tool on Consumer Buying Behaviour in Selected Supermarkets in Nairobi City County, Kenya
}

\author{
Ayoma C. Adhiambo', Wanjira Jane ${ }^{2}$
}

${ }^{1}$ Student, Master of Business Administration (Marketing), School of Business, Kenyatta University, Kenya

${ }^{2}$ Department of Business Administration, School of Business, Kenyatta University, Kenya

\section{ABSTRACT}

Consumer purchasing habits have remained a challenge for marketers to grasp, and studies have suggested that the construct can be best grasped through marketing communication stimulus that is planned and implemented in the organization. However, empirical research into consumer purchasing behavior in retail supermarkets has been limited and anecdotal, particularly in Kenya, where several stores have gone bankrupt and others are trying to stay afloat. In light of this, the purpose of this study was to look at how marketing communication tools affect consumer purchasing behavior in selected supermarkets within Nairobi City County, Kenya. The tools in marketing communication adopted included; sales promotion, personal selling, direct and digital marketing. Descriptive together with the explanatory research design were applied. Customers were the study's population, with a sample size of 370 customers established using the Yamane method. The respondents for the study were chosen using the convenience sample method. Questionnaire were used in obtaining the study's primary data. The instruments' validity and reliability were evaluated to identify the acceptability and adequacy of the research items. The collected information was analyzed utilizing descriptive and inferential analytical methods. The data was analyzed using both descriptive and inferential statistical methods. At the 0.05 level of significance, the multiple regression approach was employed to examine the significant influence of the hypotheses formulated in this study. Research results have shown that in a sample of Nairobi City County supermarkets, consumer purchasing behavior has been significantly influenced by the integrated development of advertising communication technologies. Personal sales, direct marketing, and digital marketing, according to the findings, have had a substantial impact on consumer shopping behavior at selected supermarkets in Nairobi City County, Kenya. Advertising and sales promotions, on the other hand, were shown to have no effect on consumer behavior in a few supermarkets. Although the lack of a link between advertising and sales promotion and consumer buying behavior is indicated by the findings of insignificant effects, marketing firms may still need to focus their efforts on increasing advertisements and promotion in sales as instruments in attracting customers' desires on what is offered in the market. It is recommended that Kenyan supermarket managers use the findings to better understand people's perceptions of market offerings and information exchange on what defines public behavior.

Key Words: Marketing Communication Tool, Digital Marketing, Personal Selling

DOI 10.35942/ jbmed.v3i2.195

\section{Cite this Article:}

Adhiambo, A., \& Wanjira, J. (2021). Marketing Communication Tool on Consumer Buying Behaviour in Selected Supermarkets in Nairobi City County, Kenya. International Journal of Business Management, Entrepreneurship and Innovation, 3(2), 90-105. https://doi.org/10.35942/jbmed.v3i2.195 
International Journal of Business Management, Entrepreneurship and Innovation, Volume 3, Issue 2, 2021, PP 90-105, ISSN 2707-8027

BMNED

\subsection{Introduction}

Because what determines and shapes behavior differs greatly across individuals, families, communities, peers, regions, countries, and other factors, human behavior remains a difficult topic to explain. As a result, understanding consumer purchasing behavior is critical for optimal product positioning and gaining a competitive edge. Consumers are rational customers, according to Perreault, Cannon, and McCarthy (2009), and they would choose things that provide them with economic values. However, what defines economic values to one consumer may be irrelevant to another. As a result, the purchasing behavior of consumers is influenced by a variety of circumstances. Clow (2010) as cited by Mihart (2012) argue that there is a proliferation of products and services in today's dynamic and competitive globalised markets, as a result, determining the worth of a product or service is established by the target market's thoughts and actions. As a result, marketers focus their energies on using marketing communication tools to influence people's perceptions of value and behaviors (Omboi \& Mutaly, 2011). To guarantee that communications channels transmit a clear and consistent message about the firm and its products, the firm used various combinations of strategic marketing communication tools. These promotional pull methods or tools are a specialized combination of marketing communication tools used by marketers to achieve marketing communication and overall marketing objectives, such as advertising, public relations, direct marketing, sales promotion, personal selling, and loyalty card programs (Leppäniemi \& Karjaluoto, 2008; Meyer-Waarden, 2008). However, empirical research into the marketing communication strategies used by retail stores to impact consumer purchase behavior has mainly remained anecdotal.

Individuals and groups select, acquire, utilize, or to meet needs and wants, people sell things, services, experiences, or ideas, which is referred to as consumer buying behavior (Ramya \& Ali, 2016). Consumer buying behavior, according to Sharma (2014), ultimate consumers, or individuals and households who purchase market offers for personal consumption, engage in purchasing behavior. Consumer purchasing behavior is defined by Lawan and Sanna (2013) as attitudes that reflect patterns of customer selections in a comparable way. Consumer buying behavior, according to Rani (2014), can be defined as the buying behavior of ultimate customers in connection to the decision-making process, brand loyalty, shopping habits, and retailer patronage. As a result, Furaiji, Łatuszyńska and Wawrzyniak (2012) indicate that consumers play three unique roles in the market: users, payers, and buyers of the value given. The purchasing patterns of ultimate customers, such as individuals and households, are referred to as consumer buyer behavior, in which the primary motivation is to buy things for personal consumption (Ramya \& Ali, 2016). According to a review of marketing literature, what influences consumer purchase behavior varies among situations or globally. In a global environment, according to DeMooij (2003), consumer buying behavior is more divergent than convergence. Using Hofsted's cultural orientation dimensions, DeMooij demonstrated how customers' purchasing behaviors change considerably in Individualistic, collectivist, high and low power distance, macho as well as feminism, and countries with high and low uncertainty. Consider people's reactions to market offerings in individualistic economies such as France and the United Kingdom. In collectivist continents such as South America and Africa, the United States of America, Canada, Spain, the Netherlands, Germany, and a portion of Asia are not the same.

Several factors (both marketing and environmental events) impact consumer purchase intentions around the world, and the endeavor to discover divergence of consumer buying behavior via cultural characteristics is an important component of that effort. Marketers have always influenced numerous stimuli at various points, according to Blythe (2013), in order to 
International Journal of Business Management, Entrepreneurship and Innovation, Volume 3, Issue 2, 2021, PP 90-105, ISSN 2707-8027

\section{BEMED}

position market products to get value from consumers. Marketers can affect actual behavior to achieve market offerings in a variety of methods, Using attractive speech and imagery to affect emotions, presenting relevant information at the correct time, and providing acceptable environmental stimuli to encourage purchases are just a few examples. According to Hill (2010), consumer attraction techniques are significant marketing communication tools that businesses may employ to place their products and services in front of specific markets. Consumer buying behavior is difficult to anticipate, as experts have stated simply, yet there are key aspects that have been discovered as influencers (Kotler, 2010). External elements like as product, price, location, and promotion, when it comes to acquiring a product, brand, or idea, external elements such as cultural, social, personal, and psychological components influence customer buying behaviour (Furaiji et al., 2012).

Internal and external stimuli are frequently integrated and addressed as part of a model for evaluating what motivates client buying behavior in a specific target market (Solomon, 2013; Antonides and Raijij, 2009). In the literature, consumers of products and services exhibited a variety of behavioral labels such as complexity, reduced dissonance, familiarity, diversity, general reaction, and dynamic purchases (Kotler, 2010; Liao, Shen, \& Chu, 2009). Marketers can segment the market and target individual customers by leveraging both internal and environmental cues that influence these behavioural results (Furaiji, et al.,2012). Kenya's first supermarket, the world's first, opened in 1960. (Irungu \& Wajau, 2011). Uchumi supermarket, which opened in the 1970s, and Nakumatt store, which opened in 1987, were the two largest and most popular supermarkets at the time (Irungu \& Wanjau, 2011). Supermarkets are retail chains that act as marketing intermediates, producing goods and selling them straight to customers (Mungai, 2016). According to Mageto (2009), as referenced by Mungau (2016), Nairobi houses the majority of Kenya's supermarkets, working for high-income, middle-, and low-income consumers. Kenya's food sector is separated into three distinct categories: first, second, and third.

Kenya has a plethora of retail outlets where a large number of people shop on a regular basis for home items and products, and some of these retail businesses have recently had operational issues. Due to operating challenges, some of them have had to close their doors and file for bankruptcy. Two supermarkets and the Turskys supermarket were first class and accounted for 65 per cent of domestic capital ahead of the ongoing crisis in Uchumi and Nakamatt stores, Ukwala and Naivas second-tier supermarkets accounted for 28 per cent in Kenya's supermarkets, approximately 40 supermarkets, as well as other small chain stores. On the third level, there are private stores. Increased urbanisation, a growing middle class, changing lifestyles, and market liberalisation have resulted in fierce competition among Kenyan supermarkets (Ouma, 2018; Irungu \& Wanjau, 2011), demanding the use of strategic marketing communication tactics by supermarket management to appeal to potential customers.

\subsection{Study Problem}

Kenyan supermarkets are dealing with a number of difficulties, including stiff rivalry, bad management, and poor strategic decisions, among others, which has resulted in the closure of several of them (Mungai, 2016). Uchumi and Nakumatt supermarkets are among the leading retail chain retailers those that have gone bankrupt, resulting in the closure of practically all of their branches across the country. Job losses, consumer apathy, and diminishing government revenues are all consequences of the crisis. While new supermarkets are cropping up despite the ongoing crisis afflicting the once-dominant retail chain stores, empirical research into the marketing communication strategies used by some retail chain stores to influence consumer buying behavior is required. Consumer buying behavior in Kenya has been studied empirically, although conclusions have focused on cultural, political, legal, social, and rather than consumer 
International Journal of Business Management, Entrepreneurship and Innovation, Volume 3, Issue 2, 2021, PP 90-105, ISSN 2707-8027

BNED

buying behavioural patterns, cultural influences are important (Omondi, 2018). Furaiji, et al. (2012) observe that while there is strong evidence in the literature of the relationships between marketing communication tools have both positive and bad aspects and types of customer purchasing behaviors, there is no technical data in Kenya. Despite the fact that there is evidence in the literature of both a significant and insignificant association between marketing communication techniques and behavioral outcomes (Afande \& Maina, 2015; Mendez, et al., 2015; Baisya, \& Sharma, 2010), research in Kenya has remained anecdotal and limited. Furthermore, because retail supermarkets are retailers who offer producers' household brands to end users, academics have focused their empirical research on the impact of marketing communication push tactics against strategies for marketing communication pull. This study deviates from the norm by examining the empirical impact of marketing communication tools on consumer purchasing behavior in a sample of retail supermarkets in Kenya's County.

\subsection{Study Objectives}

i. Determine how advertising affects consumer buying behaviour of selected retail supermarkets in Nairobi County in Kenya

ii. To assess how sales promotion affects consumer buying behaviour of selected retail supermarkets in Nairobi County in Kenya

iii. To evaluate how personal selling affects consumer buying behaviour of selected retail supermarkets in Nairobi County in Kenya

iv. To find out how direct marketing affects consumer buying behaviour of selected retail supermarkets in Nairobi County in Kenya

v. To find out how digital marketing affects consumer buying behaviour of selected retail supermarkets in Nairobi County in Kenya.

\subsection{Literature Review}

\subsection{Review Theoretical Literature}

\subsubsection{Stimulus-Response Model of Consumer Behaviour}

In his book "Marketing Management," published in 1967, Philip Kotler proposed the stimulusresponse paradigm. Through the mediation functions of consumer qualifications and the decision-making process, a stimulus response model, also known as a black box behavior code, has been used to describe the occurrence of a retail purchase response response (Chauhan, 2013). The refreshing response paradigm was developed to focus on the interaction of advertising indicators and consumer responses rather than what is happening inside the consumer (Vijayalaskshmi \&Mahalaksmi, 2013). In his book "Marketing Management," published in 1967, Philip Kotler proposed a refreshing response paradigm. The stimulus response model, more commonly known as the black box behavior model, has been used to describe the occurrence of a combination of purchasing impacts, according to Chahan (2013), on mediation of consumer signals and decision-making processes. The refreshing response paradigm is designed to focus on the interaction of marketing strategies and customer responses rather than within the consumer.

In marketing literature, the stimulus response paradigm has often been used to explain how adversities influence consumer behavior and decisions (Furaiju, et al., 2012). Muslims et al. (2018) used a stimulus response model to conduct their study on social comparisons, materialism, and forced purchases between young and young consumers. Weilbacher (2003) used the stimulus-response paradigm to investigate how advertising influenced customer purchasing decisions for items and services. According to Kanagal (2016), the stimulusresponse model is effective for explaining individual consumer purchasing behavior and provides a fuller explanation of aggregate buyer characteristics. The motivational response 
International Journal of Business Management, Entrepreneurship and Innovation, Volume 3, Issue 2, 2021, PP 90-105, ISSN 2707-8027

\section{BMAE}

model was employed as a whole in this study to show how marketing communication methods (advertising, marketing promotion, direct marketing, and personal marketing) are expected to have a direct impact on certain customer purchasing behaviors. Kenyan supermarket.

\subsubsection{Attention, Interest, Desire, and Action Model}

In 1982, Strong created the AIDA (attention, interest, desire, and action) models. AIDA is a model of behavior that emphasizes awareness, arouses interest and leads to aspirations, leading to consumer purchases (Karlsson, 2007). To be effective, marketing communication (advertising) must be able to command attention, arouse interests, lead to desires, and finally result in actions, according to Strong's AIDA model. According to the literature review, marketing experts have used this model to describe the many categories in which advertising communication tools influence consumer decisions and behavior (Brierley, 2002). Hadadiati (2016) investigated the relationship between the integration of marketing and online shopping in Indonesia using the AIDA model. Hassan, Nadzim, and Zaleha (2015) used the AIDA model as a basic concept to explain how small businesses effectively use social media. Furthermore, according to Mohammandi and Esmaeily (2012), the AIDA model's main idea explained why advertising approaches in the sports industry are prioritized. Although AIDA has been criticized for only representing or explaining high-involvement transactions, used as a basic theory in marketing-related research, showing how marketing communication tools are important in helping to understand customer buying behavior; however, it has been criticized for representing or interpreting only high transactions (Brierley, 2002). Despite the criticism, marketing academics are intrigued by the concept. In this study, the AIDA model was utilized to explain how communication tools produce or influence consumer shopping behavior in a few supermarkets in Nairobi City, Kenya.

\subsubsection{Hierarchy of- Effect- Theory}

In 1969, Lavidge and Steiners were credited with developing the hierarchy-of-effect hypothesis. The hypothesis was released about the same time as Russell and Colley's DAGMAR model. According to Karlsson (2007), the hierarchy-of-effect theory asserts that customers go through a series of actions and procedures before becoming convinced to buy market items (products). Karlsson (2007) observe that awareness, knowledge, liking, preferences, conviction, and purchases are the processes that might stimulate consumer purchasing decisions, according to the hierarchy-of-effect hypothesis. According to the notion, marketers can use the procedures or techniques for developing marketing communication tools that influence consumer buying decisions. The concept of job sequence has been questioned because not all consumers go through all the steps before acquiring a product (Mackay, 2005). However, it has become the lens of critical scholarly beliefs that learns how marketing strategies affect consumer buying behavior (Mathew, Ali, \& Thomas, 2014; Nesse \& Haymie, 2015). To investigate the relationship between marketing and consumer communication tools at selected supermarkets in Nairobi City County, Kenya, operating theory has been used as a basic theory.

\subsection{Empirical Literature Review}

Numerous studies have shown that marketing strategies such as advertising have a profound effect not only on the performance results of companies, but also on the behavior and purchasing power of consumer decisions. International art research on the impact of advertising on personal and organizational outcomes is registered in all cases. A link between alcohol advertisement and young use in New Zealand was established by Smith and Foxcroft (2009). Boyland and Halford (2013) discovered a favorable association linking advertising through television and kid food behavior and favourites in UK, concluding that advertising had a major 
International Journal of Business Management, Entrepreneurship and Innovation, Volume 3, Issue 2, 2021, PP 90-105, ISSN 2707-8027

BMED

impact on branding. Mir (2012) discovered that social media advertising and online purchase behavior showed a substantial link using a survey of university students in Islamabad, Pakistan. Saleem and Abideen (2011) established a favorable relationship between advertising and consumer buying behavior of different brands of goods in a study conducted in Pakistan using regression analysis method. The study, however, did not provide a comprehensive description of the criteria used to measure consumer purchasing behavior.

Kumar and Raju (2013) used a survey sample size of 110 respondents to conduct a powerful In India, a study was conducted on the impact of advertisement on customer decision-making. The Chi-square test was used in the research as a statistical tool to examine how advertising influences consumer decision-making, and the data demonstrated that there was a link between advertising ability and customer behavior when it came to purchasing products and services. The study is significant because it discovered a substantial link; however, to establish the causal effect of advertising on customer purchasing behavior, an empirical analysis utilizing a robust statistical methodology is required. A number of research studies on advertising and its effects on attitudes and behaviors in Africa have shown substantial evidence of a correlation. In a study conducted by Ayanwale, Alimi, and Adebimpe, it was discovered that advertising influenced customer brand selection for many food and beverage brands in Nigeria (2005). Nantey (2010) discovered, in a similar vein, that advertising has a significant impact on client purchase behavior in Ghana. Kibona (2015) used a data analysis method from 200 Coca-Cola beverage users in Tanzania and found a significant advertising effect on consumer purchasing behavior. Several of these studies in Sub-Saharan Africa lacked theoretical foundations and used inappropriate analytical methods.

There has been evidence in Kenya of a positive relationship between advertising and consumer purchasing behavior in various fields. In Kenya, Afande and Maina (2015) established a link between bank advertising and sales volume. Similarly, Omondi (2017) investigated the principles of local Kenyan tourist shopping, to find a significant advertising effect, and Ogutu, Ogutu, and Njanja (2014) found a significant impact of international advertising on consumer purchases. target of university students in Kenya. Priya et al. (2010), on the other hand, found no evidence of a substantial influence of television advertisements on children's purchasing behavior in India. As a result of active advertisement mediation, according to Buijzen, advertising has a significant impact on children's food consumption (2009). Evidence of advertising influence on consumer purchasing behavior types, both large and minor, needs to be researched further.

Academics have provided both positive and negative findings in a number of powerful studies of the impact of sales promotions on customer behavior. Mendez et al. studied art in their research (2015) found that increased sales have a significant impact on product reliability among home buyers in Puerto Rico, Spain. In a literature study, Hawkes (2009) found a significant increase in sales due to the influence of marketing efforts, but not a change in consumer food patterns. Diverse methods of sales promotions generate different promotional responses and behavioral effects, according to a number of studies. According to Mendez et al. (2015), a customer's past purchase's promotional status can impact their brand choice. Customers respect personal information upon receipt of products or services that may purchase those items or services even if the promotion is complete. Customers who respect personal information after purchasing products or services, even if the promotion is over, may purchase those products or services. Bridges, Briesch and Yin (2006) indicate that marketing promotions, on the other hand, can reduce product reliability, customers who respect personal information after purchasing items or services, even if it is overdue, may purchase those products or services, especially if pricing is a factor in the marketing campaign mix. 
International Journal of Business Management, Entrepreneurship and Innovation, Volume 3, Issue 2, 2021, PP 90-105, ISSN 2707-8027

BMED

Neha and Manoj (2013) did a study on methods of encouraging retailers have been found to have a significant impact on consumer refrigeration purposes in India. Accordingly, Oyeniyi (2011) found a link between promotional marketing and customer loyalty in the Nigerian telecommunications industry. Afande and Maina (2015) discovered a substantial influence of sales promotion on sales volumes in a research of the effect of promotional mix elements in financial institutions in Kenya. The influence of sales promotional activities, on the other hand, may have an inverse relationship with behavioral consequences. Yusuf (2010) claimed that sales promotion efforts in Ghana had a negative impact on Muslim customers' ethical standards. To make effective selections about marketing communication strategy, empirical research on the large impact of marketing tools on customers buying ethical practices is required.

The impact of human behavior on marketing on performance results has brought various results to the arts research (Konrad, 2018). Using research data from 384 respondents, In Lagos, Nigeria, Onigbinde and Odunlami (2015) conducted a detailed study of the impact of product image and promotional techniques on beverage consumers. Personal marketing, as one of the promotions, has had a substantial impact on consumer purchase decisions among beverage customers in Nigeria, according to the conclusions of the study, which were based on the results of Pearson's product integration. The direct link between personal marketing practice and client satisfaction has also been proved to be statistically significant in a powerful study.Furthermore, Sadek et al. (2016) conducted a thorough investigation on the impact of personal sales on banking prices in Egypt. Research findings were based on a survey of 465 bank clients, revealed that personal selling, as a key marketing message, had a considerable impact on bank brand equity in Egypt. In the Kenyan setting, Kihanya (2013) discovered a favorable and significant association between personal selling and performance in the insurance industry a study was conducted to determine the impact of integrated marketing communication on the success of a company of a business Murithi (2015) identified a significant correlation between personal selling and sales among a sample of women in Kenya's Meru County in a similar vein. Wang, Chen, and Chang, on the other hand, discovered that personal selling has a negative influence on consumption in Taiwan (2012). As a result, personal selling may have a negative impact on consumer behavior intentions. While data from retail supermarkets in Kenya it should be used to investigate the significant effect of human trafficking on consumer purchasing behavior, and there is a need to accept both relevant and insignificant evidence of personal sales as concomitant thinking, behavioral, and performance outcomes.

Direct marketing has a number of advantages, including increased sales from current and past consumers and improved loyalty programs. Direct marketing has a favorable association with behavioural and performance results, according to empirical evidence in the literature. In a survey of Fortune 500 B2B service organizations, Kim and Kumar (2018) found a strong marketing effect directly on consumer purchasing behavior. Muhanji and Ngari (2015) discovered substantial linkages between direct marketing as part of marketing communications and the operation of commercial bank sales in Kenya in a related study. An evaluation on how methods in marketing communication affected student admission in private Kenyan Universities. It was observed that direct marketing had a major impact on student enrollment in Kenya's private universities. In a similar line, Kihanya's (2013) study found that direct marketing had a significant impact on Kenya's insurance industry's performance. Although evidence of a strong association between direct marketing and performance is important for understanding the marketing communication tools-performance relationship, more research is needed to see if direct marketing as a communication tool can predict consumer purchasing behavior. 
International Journal of Business Management, Entrepreneurship and Innovation, Volume 3, Issue 2, 2021, PP 90-105, ISSN 2707-8027

EEN

A number of factors have been identified as influencing marketers' use of digital marketing to attract new customers. According to Di Pietro and Pantano (2012), one of the reasons why organizations utilize digital marketing is the link between fun and the use of online marketing tools. Furthermore, empirical research have demonstrated a link between digital marketing and customer purchase behavior. According to Nizar and Janathanan, digital marketing has a significant impact on customer purchasing behavior in Sri Lanka (2018). In a similar vein, Dahiya and Gayatri (2018) discovered that digital marketing communication had a considerable impact on consumer purchase decision-making in India. There has been limited research into the relationship between digital marketing communication tools and customer buying behavior in Sub-Saharan African countries, particularly Kenya. The impact of digital marketing on banking performance has been the subject of numerous research papers (Ng'ang'a, 2018). Jalang'o (2017) study explored how digital advertising affected the Kenyan commercial banks' performance. Data study revealed that banks in Kenya were shifting their attention away from traditional forms of advertising such as television, radio, and newspapers, moving away from traditional channels of communication including email, smartphone apps, and social media.

\subsection{Conceptual Framework}

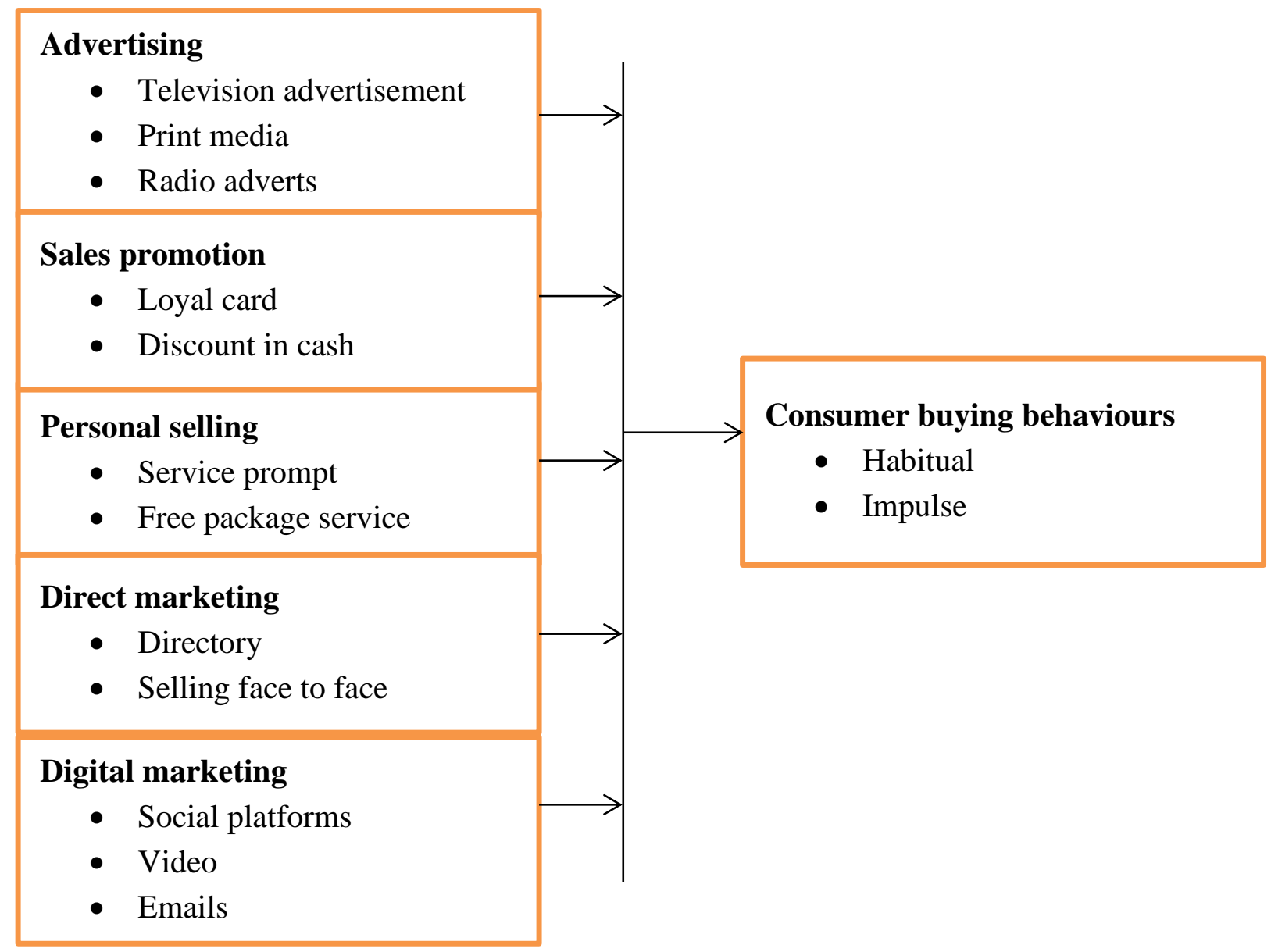

\section{Figure 1: Conceptual Framework}

\subsection{Methodology}

The descriptive design was adopted for the study to outline the characteristics of the survey data that would be collected. The researcher was able to analyze the data obtained and 
International Journal of Business Management, Entrepreneurship and Innovation, Volume 3, Issue 2, 2021, PP 90-105, ISSN 2707-8027

EDMED

understand the aggregate replies and deviations from the research questions thanks to the descriptive design. To explain how the two variables related, an explanatory design was adopted. Customers who shop at the top five main retail supermarkets in Nairobi, Kenya, made up the study's population. Because the study's population is unlimited, the researcher 60 percent of customers at the selected stores are expected to participate in the trial.

In the process of determining the size of the sample a $\mathrm{Z}$ statistical method was adopted due to infinite nature of the population. This is how the $\mathrm{Z}$ statistic is written:

$$
\mathrm{SS}=\left[\mathrm{Z}^{2} \mathrm{P}(1-\mathrm{P})\right] / \mathrm{C}^{2}
$$

The response percentage is set at $60 \%$, and the normal standard deviation is set at a level of $95 \%$. As a result, the sample size is calculated in the following manner:

$$
\begin{aligned}
& {\left[1.96^{2}(0.6)(1-0.6) / 0.05^{2}\right.} \\
& =3.8416[0.6](0.4) / 0.025 \\
& =0.921984 / 0.0025 \\
& =370
\end{aligned}
$$

This study sample was 370 respondents distributed in all the 5 supermarkets studied. The sample size was allocated evenly across the five retail supermarkets that were chosen. A convenience sampling method was employed to pick respondents in each supermarket. Researchers in empirical studies have used convenience sampling technique, which is often regarded as a reasonable sample technique for picking respondents from a finite population (Neha \& Manoj, 2013).

In this study, data were collected using two methods: a survey questionnaire and an online questionnaire management. Respondents were given a list of questions at designated supermarkets. Some respondents were in a hurry, therefore after hearing about the purpose of the data collection, they consented to participate online by providing their mobile number willingly. The respondents who volunteered to participate in the online survey procedure were sent an online survey questionnaire that had been previously produced using a social media platform (WhatzApp). All respondents of the five selected supermarkets received a total of 372 questionnaires (both face to face and online surveys), with each supermarket receiving 74 questionnaires in total. The features of the research data were presented using descriptive statistics such as standard deviation and standard deviations. The mathematical strategy used was to manipulate many statistics. The choice of return method is largely influenced by the nature of the combination (combination marketing tools), measured in this study using subtle variables (advertising, marketing promotion, personal marketing, direct marketing, and digital marketing). Data collected, coded, organized, and evaluated in this study were presented in tables.

\subsection{Data Analysis Results}

Inferential analysis was performed using the SPSS). Researchers used regression analysis to determine whether the variables in the study were related. As a result, the study's findings are summarized in Tables 1 and 2 in this part as Model Summary and Analysis of Variance (ANOVA) Summary, respectively.

Table 1 Model Summary

\begin{tabular}{llllc}
\hline Model & $\mathrm{R}$ & $\mathrm{R}^{2}$ & Adjusted $^{2}$ & Standard Error of Estimate \\
\hline 1 & 0.577 & 0.33 & 0.320 & 4.649 \\
\hline
\end{tabular}


The values of 0.577 represented by $\mathrm{R}$ is an indicator independent variable and dependent variable have a significant and favorable relationship. The findings of a favorable and significant correlation between marketing communication tools and client purchase behavior are consistent with previous research findings (Furaiji, et al., 2012; Ogachi, 2014). Table 11 shows that the predictors of marketing communication tools together explained 33.3 percent of the variation in independent variables studied. As a result of these findings, other variables not considered in this study can explain 66.7 percent of the variation in customer buying behavior. However, the variance explained suggests that numerous factors, not just marketing tactics, influence customer purchasing behavior. The degree of variation in customer purchasing behavior explained by the composite construct of marketing communication tool implies that the regression model is capable of considerable prediction. According to the model summary, in a sample of Nairobi City County supermarkets in Kenya, the independent variables are significantly and positively relatedwith the dependent varibale. Prior research have discovered evidence of considerable consumer purchase behavior prediction by a company's marketing communication tools, and the findings showing a strong correlation are consistent with those findings. Two recent examples are Milhart (2012) and Jalong'o (2015).

Table 2 ANOVA

\begin{tabular}{lllllll}
\hline Model & & Sum of square & df & Mean square & F & Significance \\
1 & Regressions & 2765.1 & 5 & 533.01 & 25.6 & 0.000 \\
& Residuals & 5531.8 & 256 & 21.61 & & \\
& Total & 8296.83 & 261 & & & \\
\hline
\end{tabular}

Because the value of $p$ is .000 , Table 2 shows that the value of $F(25.592)$ is statistically significant. Therefore, there was consistency of data obtained and an important predictions of link between the construction of advertising communication tools and the purchasing behavior of customers.

\section{Table 3 Hypothesis Tests}

\begin{tabular}{lcllcl}
\hline Model & \multicolumn{2}{c}{ Unstandardised } & Standardised & & \\
1 & \multicolumn{2}{c}{ Coefficients } & Coefficients & $\mathrm{t}$ & Sig. \\
& $\mathrm{B}$ & Std Error & Beta & & $\mathrm{P}<0.05$ \\
\multicolumn{1}{c}{ Constant } & 15.838 & 1.459 & & 10.86 & 0.00 \\
Advertising & 0.045 & 0.047 & 0.066 & 0.945 & 0.346 \\
Sale promotion & 0.52 & 0.086 & 0.41 & 0.601 & 0.548 \\
Personal selling & 0.241 & 0.070 & 0.241 & 34.23 & 0.001 \\
Direct marketing & 0.267 & 0.106 & 0.173 & 2.508 & 0.013 \\
Digital marketing & 0.224 & 0.80 & 0.197 & 2.800 & 0.005 \\
\hline
\end{tabular}

The study's first hypothesis was put in null form, stating that advertising as a marketing communication medium has no meaningful impact on customer purchasing behavior. The regression parameters $(\mathrm{t}=.945,=.045, \mathrm{p}=.346)$ show that the ultimate rejection of null hypothesis. As a result, advertising has been determined to have a negligible impact on consumer behavior at a few selected supermarkets in Nairobi City County, Kenya. Although the investigation found that a unit increase in advertising resulted in a.045 rise in consumer 
International Journal of Business Management, Entrepreneurship and Innovation, Volume 3, Issue 2, 2021, PP 90-105, ISSN 2707-8027

BMED

buying behavior, the association is negligible and hence has no value. The findings demonstrating that according to Omondi (2017) advertising does not have a significant impact on consumer purchasing behavior as opposed to findings in many articles and studies showing that advertising has a significant impact on performance-related outcomes.

The hypothesis that sales promotion do not significantly relate with consumer buying behaviour. A non-significant influence of sales promotions on consumer buying behavior in a sample of Kenyan supermarkets was found $(\mathrm{t}=0.6, \mathrm{p}<0.05)$. Thus the hypothesis was not rejected. The lack of evidence of a substantial effect does not rule out the possibility of supermarkets in Kenya engaging in sales promotions, but such efforts did not have a significant impact on how customers purchased things at supermarkets. According to Neha and Manoj (2013) the lack of a substantial effect in this study contrasts with the majority of prior findings, which showed that sales promotions have a considerable impact on customer purchasing behavior.

The null hypothesis was that personal selling had no substantial impact on consumer purchase behavior in a certain supermarket. The values $(\beta=0.24, \mathrm{t}=3.42, \mathrm{p}<0.001)$ indicate that the null hypothesis that personal selling has no effect on consumer purchasing behavior is not accepted. This also explains why there is a statistically significant link between personal selling and customer purchasing behavior. Based on the findings, a rise in personal selling leads to a.241 increase in consumer purchasing behavior. These findings suggest that personal selling, as a marketing communication method used in Kenyan supermarkets, has an impact on consumer purchasing behavior. The results of this study are consistent with previous research findings by Murithi (2015) that personal selling has a major impact on consumer purchasing behavior.

The study's fourth goal was to determine if direct marketing has a major impact on consumer purchasing behavior, and the associated hypothesis was that direct marketing has no substantial impact on consumer purchasing behavior. Values of $(\beta=0.27, t=2.51, p<0.05$ indicate that the hypothesis of a significant direct marketing effect is statistically significant, implying that direct marketing has a considerable impact on customer purchasing behavior. The findings also revealed that direct marketing played a substantial role in explaining consumer purchasing behavior, with a unit increase in direct marketing resulting in a.106 rise in consumer purchasing behavior. The outcomes of this study are likewise in line with prior research findings by Kihanya (2013) that show a favorable and significant effect of direct marketing on consumer purchasing behaviour.

Furthermore, the study investigated the impact of digital marketing on consumer behavior in a few select supermarkets in Nairobi City County, Kenya. Digital marketing would have no significant impact on consumer purchasing behavior at a certain supermarket, according to the corresponding hypothesis. As mentioned in Table 4.13, value of $(\mathrm{t}-2,8)$ produced a a significant result $(\mathrm{p}=.05)$, showing a statistical significance of between variables. In addition, one unit increase in digital marketing caused a $\beta=.224$ rise in the beta coefficient. As a result of the 244 increases in customer purchasing behavior, it is determined that digital marketing aids in the prediction and explanation of consumer purchasing behavior. The findings as per Jalang'o (2015) study indicate a strong effect of digital marketing on customer purchasing behavior.

\subsection{Conclusions and Recommendations}

\subsection{Conclusion}

Advertising was found to have a negligible impact on the purchasing habits of chosen supermarket customers in this study. This also implies that advertising, as a part of commercial communication techniques is effective, is not a factor in customers' decision-making when it 
International Journal of Business Management, Entrepreneurship and Innovation, Volume 3, Issue 2, 2021, PP 90-105, ISSN 2707-8027

BMED

comes to purchasing supermarket items and brands in Kenya. As a result, it may be stated that advertising has no influence on consumer purchasing patterns, but other aspects of marketing communication may influence customer choice(s) in relation to supermarket patronage in Kenya. In Kenya, sales advertising was likewise found to have a negligible impact on consumer purchasing behavior. These data demonstrated that customer buying behavior was not significantly influenced by sales promotions. Consumers, on the other hand, acknowledged that sales promotional activities could affect their purchasing decisions, according to the descriptive result. As a result, while sales promotion is not a vector of consumer purchasing patterns, supermarket management should increase their efforts in employing sale promotional incentives to capture customer attention to a variety of items and brands.

This study looked into personal selling as a predictor of consumer purchasing behavior. Personal selling had a considerable impact on consumer purchase behavior, according to the summary of the test of hypothesis results. As a result of these findings, it can be inferred that personal selling serves as a vector of consumer purchase behavior in a select group of supermarkets. These findings suggest that personal selling, in conjunction with other marketing communication strategies, can influence consumer purchase patterns in Kenya. At Nairobi City County, Kenya, direct marketing was found to have a considerable impact on consumer buying behavior in a number of supermarkets. As a result, direct marketing is a driving factor in driving consumers to patronize and purchase items at supermarkets in Kenya. Direct marketing is a driver of consumer purchase habits in Nairobi City County, Kenya, according to these data. This study investigated digital marketing to see if it could predict customer purchasing behavior. The findings of the study demonstrated that digital marketing had a considerable impact on consumer purchasing behavior in a number of Kenyan supermarkets. As a result of these findings, it can be concluded that internet marketing is a driver of consumer purchasing habits, particularly in Nairobi City County, Kenya. In general, this study concludes that supermarket management may strengthen marketing communication techniques including personal selling, direct marketing, digital marketing, and other parts of sales promotional activities to affect consumer buying patterns and behavior in Kenya.

\subsection{Recommendation}

Based on the foregoing conclusions, supermarket management should place a greater emphasis on marketing communication tools such as direct marketing, digital marketing, personal selling, and other promotional tools such as sales discounts, loyalty cards, and other similar tools as a means of attracting customers' attention to their respective supermarkets. The findings of this study can be used by supermarket managers in Kenya as a platform for segmenting markets based on various factors. The findings of this study will have a substantial impact on the body of marketing knowledge. Although previous research has suggested that advertising and sales promotion have a significant impact on consumer purchasing patterns, this study found that advertising and sales promotion have only a minor impact on customer purchase patterns in Kenyan supermarkets. Furthermore, the findings of this study backed up the theoretical lenses that support the relationship between marketing communication tools and customer buying behavior.

\section{References}

Boyland, E. J., \& Halford, J. C. (2013).Television advertising and branding. Effects on eating behaviour and food preferences in children. Appetite, 62, 236-241.

Buijzen, M. (2009). The effectiveness of parental communication in modifying the relation between food advertising and children's consumption behaviour. British Journal of Developmental Psychology, 27(1), 105-121. 
International Journal of Business Management, Entrepreneurship and Innovation, Volume 3, Issue 2, 2021, PP 90-105, ISSN 2707-8027

BMED

Calvert, S. L. (2008). Children as consumers: Advertising and marketing. The future of children, 18(1), 205-234.

Chang, S. C., Sun, C. C., Pan, L. Y., \& Wang, M. Y. (2015). An extended TAM to explore behavioural intention of consumers to use M-Commerce. Journal of Information \& Knowledge Management, 14(02), 1550014.

Dahiya, R., \& Gayatri. (2018). A research paper on digital marketing communication and consumer buying decision process: An empirical study in the Indian passenger car market. Journal of Global Marketing, 31(2), 73-95.

Di Pietro, L., \& Pantano, E. (2012). An empirical investigation of social network influence on consumer purchasing decision: The case of Facebook. Journal of Direct, Data and Digital Marketing Practice, 14(1), 18-29.

Furaiji, F., Łatuszyńska, M., \& Wawrzyniak, A. (2012). An empirical study of the factors influencing consumer behaviour in the electric appliances market. Contemporary Economics, 6(3), 76-86.

Hadiyati, E. (2016). Study of marketing mix and AIDA model to purchasing on line product in Indonesia. British Journal of Marketing Studies, 4(7), 49-62.

Hassan, S., Nadzim, A., Zaleha, S., \& Shiratuddin, N. (2015). Strategic use of social media for small business based on the AIDA model. Procedia-Social and Behavioral Sciences, 172, 262-269.

Hawkes, C. (2009). Sales promotions and food consumption.Nutrition reviews, 67(6), 333342.

Hooley, G., Broderick, A., \& Möller, K. (1998). Competitive positioning and the resourcebased view of the firm. Journal of strategic marketing, 6(2), 97-116.

Irungu, B. K., \& Wanjau, K. L. (2011). Effectiveness of vendor managed inventory systems in retail supermarkets in Kenya. International journal of business and public management, $1(1), 85-89$.

Islam, T., Sheikh, Z., Hameed, Z., Khan, I. U., \& Azam, R. I. (2018). Social comparison, materialism, and compulsive buying based on stimulus-response-model: a comparative study among adolescents and young adults. Young Consumers.

Johnston, M. W., \& Marshall, G. W. (2013).Sales force management: Leadership, innovation, technology. Routledge.

Kanagal, N. B. (2016). An Extended Model of Behavioural Process in Consumer Decision Making.International Journal of Marketing Studies, 8(4), 87-93.

Kibona, D. (2015). Impact of Elements of Advertisement on the Consumer Buying Behaviour in Urban Areas: The Lessons from Coca-Cola Consumers in Dar-Es-Salaam Tanzania. Asian Journal of Research in Marketing, 4(6), 47-61.

Kihanya, K. (2013). Effects of Integrated Marketing Communication on Business Performance in the Insurance Industry a Case Study of the Kenya Orient Insurance Limited (Doctoral dissertation, United States International University-Africa).

Konrad, A. (2018). The impact of salespeople customer orientation on performance: literature review. Proceedings of The 12th MAC 2018, 136.

Kotler, P., \& Keller, L. (2006).K.(2006). Marketing management, 12.

Krizanova, A., Lăzăroiu, G., Gajanova, L., Kliestikova, J., Nadanyiova, M., \& Moravcikova, D. (2019).The Effectiveness of Marketing Communication and Importance of Its Evaluation in an Online Environment.Sustainability, 11(24), 7016.

Lawan, L. A., \& Zanna, R. (2013). Evaluation of socio-cultural factors influencing consumer buying behaviour of clothes in Borno State, Nigeria. Int. J. Basic Appl. Sci, 1(3), 519529.

Leppäniemi, M., \& Karjaluoto, H. (2008). Mobile marketing: From marketing strategy to 
International Journal of Business Management, Entrepreneurship and Innovation, Volume 3, Issue 2, 2021, PP 90-105, ISSN 2707-8027

mobile marketing campaign implementation. International Journal of Mobile Marketing, 3(1).

Maina, P., \& Afande, F. (2015). Effect of promotional mix elements on sales volume of financial institutions in Kenya: Case study of Kenya post office savings bank. Journal of Marketing and Consumer Research, 11 .

Mendez, M., Bendixen, M., Abratt, R., Yurova, Y., \& O'Leary, B. (2015). Sales promotion and brand loyalty: some new insights. International Journal of Education and Social Science, 2(1), 103-117.

Meyer-Waarden, L. (2008). The influence of loyalty programme membership on customer purchase behaviour. European Journal of marketing, 42(1/2), 87-114.

Mihart, C. (2012). Impact of integrated marketing communication on consumer behaviour: Effects on consumer decision-making process.International Journal of Marketing Studies, 4(2), 121.

Mir, I. A. (2012). Consumer attitudinal insights about social media advertising: A South Asian perspective.The Romanian Economic Journal, 15(45), 265-288.

Mihart, C. (2012). Impact of integrated marketing communication on consumer behaviour: Effects on consumer decision-making process.International Journal of Marketing Studies, 4(2), 121.

Mittal, M., \& Sethi, P. (2011). The effectiveness of sales promotion tools among Indian consumers: An empirical study. Journal of Promotion Management, 17(2), 165182.

Mohammadi, S., Esmaeily, N., \& Salehi, N. (2012). Prioritization of promotion tools based on AIDA model by Analytic Hierarchy process in production sector of sport industry. Archives of Applied Science Research, 4(4), 1670-1675.

Muhanji, E. M., \& Ngari, M. B. (2015). Influence of Integrated Marketing Communication and Sales Performance of Commercial Banks in Kenya. International Journal of Scientific and Research Publications, 3(1), 234-267.

Mungai, K. K. (2016). Benchmarking Practices and Performance of Supermarkets in Nairobi County (Doctoral dissertation, School of Business, University of Nairobi)

Njoroge, J. (2017). Factors That Influence Consumer Purchasing Behaviour in the Consumption of Coca Cola Novida Malt Soft Drinks in Nairobi, Kenya (Doctoral dissertation, United States International University-Africa).

Neha, S., \& Manoj, V. (2013). Impact of sales promotion tools on consumer's purchase decision towards white good (refrigerator) at Durg and Bhilai Region of CG, India. Research Journal of Management Science, ISSN, 2319, 1171.

Nizar, N. A., \& Janathanan, C. (2018). Impact of digital marketing on consumer purchase behaviour. In APIIT Business, Law \& Technology Conference.

Ogachi, p. (2014).A comparative study of lower and middle class women's consumer behaviour towards clothing: A case study of women in Mathare Valley Estate and Garden Estate in Nairobi city county, Kenya (Doctoral Dissertation, School of Business, University of Nairobi).

Ogutu, P., Ogutu, M., \& Njanja, L. (2014). The moderating effect of subjective norms, perceived behavioral control and gender on the relationship between attitude towards internet advertising and purchase intention of university students in Kenya.

Olejniczak, A., \& Tomorad, D. (2015). Selected indicators for evaluating the effectiveness of marketing communication. Marketing of Scientific and Research Organizations, 16(2), 19-32.

Omboi, B. M., \& Mutali, N. I. J. (2011). Effect of selected marketing communication tools on student enrolment in private universities in Kenya. 
International Journal of Business Management, Entrepreneurship and Innovation, Volume 3, Issue 2, 2021, PP 90-105, ISSN 2707-8027

BEN

Omondi, S. (2017).Determinants of Consumer Buying Behaviour for The Domestic Tourists in Kenya (Doctoral dissertation, United States International University-Africa).

Ouma, D. (2018). A Proposed Model for Supermarket Branch Network Expansion in Kenya (Doctoral dissertation, JKUAT).

Oyeniyi, O. (2011). Sales promotion and consumer loyalty: A study of Nigerian Telecommunication Industry. Journal of Competitiveness|, 66-77.

Panda, R., \& Narayan Swar, B. (2013). Online Shopping: An Exploratory Study to Identify the Determinants of Shopper Buying Behaviour. International journal of business insights \& transformation, 7(1).

Priya, P., Kanti Baisya, R., \& Sharma, S. (2010). Television advertisements and children's buying behaviour. Marketing Intelligence \& Planning, 28(2), 151-169.

Ramya, N., \& Mohamed Ali, S. A. (2016).Factors affecting consumer buying behavior. International journal of applied research, 2(10), 76-80.

Saleem, S., \& Abideen, Z. (2011). Effective advertising and its influence on consumer buying behavior. European Journal of Business and Management, 3(3), 55-67.

Shu-Ling, L., Yung-Cheng, S., \& Chia-Hsien, C. (2011). The Effects of sales promotion strategy, product appeal and consumer traits on reminder impulse buying behavior (vol 33, pg 274, 2009). International Journal of Consumer Studies, $35(5), 601-601$.

Smith, K. T. (2012). Longitudinal study of digital marketing strategies targeting Millennials. Journal of Consumer Marketing, 29(2), 86-92.

Smith, L. A., \& Foxcroft, D. R. (2009). The effect of alcohol advertising, marketing and portrayal on drinking behaviour in young people: systematic review of prospective cohort studies. BMC public health, 9(1), 51.

Sommers, M. S., \& Barnes, J. G. (2007).Marketing: A Customer-Centric Approach. McGraw-Hill Ryerson.

Šramová, B. (2015). Marketing and media communications targeted to children as consumers. Procedia-Social and Behavioral Sciences, 191, 1522-1527.

Taiminen, H. M., \& Karjaluoto, H. (2015). The usage of digital marketing channels in SMEs. Journal of Small Business and Enterprise Development.

Tandwilina Gunadi, Y., Secapramana, H., \& Verina, L. (2018). The Impact of Personal Selling Orientation to Value Creation, Relationship Development, and Customer Satisfaction in Industrial Business.

Wang, E. S. T., Tsai, B. K., Chen, T. L., \& Chang, S. C. (2012). The influence of emotions displayed and personal selling on customer behaviour intention. The Service Industries Journal, 32(3), 353-366.

Weilbacher, W. M. (2003). How advertising affects consumers. Journal of Advertising Research, 43(2), 230-234.

Ye, L. R., \& Zhang, H. H. (2014). Sales promotion and purchasing intention: Applying the technology acceptance model in consumer-to-consumer marketplaces. International Journal of Business, Humanities and Technology, 4(3), 1-5.

Yu, W., Ramanathan, R., \& Nath, P. (2014). The impacts of marketing and operations capabilities on financial performance in the UK retail sector: A resource-based perspective. Industrial Marketing Management, 43(1), 25-31.

Yusuf, J. (2010). Ethical implications of sales promotion in Ghana: Islamic perspective. Journal of Islamic marketing, 1(3), 220-230.

This is an open-access article published and distributed under the terms and conditions of the (c) (i) \& Creative Commons Attribution 4.0 International License of United 
International Journal of Business Management, Entrepreneurship and Innovation, Volume 3, Issue 2, 2021, PP 90-105, ISSN 2707-8027

IBMED

States unless otherwise stated. Access, citation and distribution of this article is allowed with full recognition of the authors and the source. Copyright, content ownership and liability for content herein remain with the authors. 